\title{
The attitudes of Teachers of Learning Disabilities in English Language Toward Using Virtual classes to Teach English Writing
}

\author{
Mohamad Ahmad Saleem Khasawneh ${ }^{1}$ \\ Email: mkhasawneh@kku.edu.sa \\ ${ }^{1}$ Assistant Professor, Special Education Department, King Khalid University, Saudi Arabia \\ Received: September 21, 2021 \\ Received in Revised: October 20, 2021 \\ Accepted: October 29, 2021
}

\begin{abstract}
This study investigated the attitudes of teachers of learning disabilities in English toward the use of virtual classrooms and e-learning in teaching writing skills to students with learning disabilities. The study adopted the descriptive approach and was applied to a sample of 65 teachers from Irbid city, Jordan. A questionnaire was developed to achieve this purpose after being checked for validity and reliability. The results showed that teachers' attitudes toward virtual classes varied between high and moderate. For the realm of e-learning in general, the attitudes were high while for the realm of the effect of virtual classes in teaching writing skills were moderate. The study recommended providing intensive training to teachers of LDs in English language on the usages of e-learning and supporting teachers and students with the appropriate tools.
\end{abstract}

Keywords: Learning Disabilities in English Language, Attitudes, Virtual Classrooms, ELearning, Teachers

\section{Introduction}

Technology has massively gained popularity in the 1990s and the 2000s. All the domains of life have been connected and controlled by computers, the net, and other electronic innovations. Therefore, decision-makers and teachers have attempted to introduce new methods to meet the requirements of the current period (Alkhawaldeh, 2020). For example, some students have replaced regular books with electronic resources that are uploaded on small devices like minilaptops and smartphones (Harper et al., 2004). Furthermore, many teachers have developed a tendency to use many technological aids inside their classes to involve their students in the learning process.

The use of technology introduced new dynamics to the relationship between the teacher and the student in the classroom (Alkhawaldeh \& Kha-sawneh, 2020). In e-learning, the teacher usually becomes the facilitator of the learning process by being a mentor and a guide to students (Khasawneh, 2021). He usually corrects students when they make mistakes and gives them instructions on the best ways of carrying on specific tasks (Alkhawaldeh \& Khasawneh, 2021). The use of technology in education increases students' motivation to learn by engaging them in interactive activities and stimulating real-life events to give them real lessons (Wichadee, 2013; Khasawneh, 2012). For instance, using videos in education triggers the students' senses and their cognitive functions. On the other hand, most of the conventional teaching methods gives more power to the role of the teacher as the main source of information and reduces the students' participation in the learning process (Sayed \& Baker, 2015).

In the case of students with learning disabilities, they face challenges specific to their category. They have a special kind of focus that is different from regular students. They need special attention and customized teaching programs (Khasawneh, 2021). 


\section{The problem of the study}

Students with learning disabilities usually own special listening, speaking, reading, and grammar knowledge. When it comes to writing, they face several challenges in writing sentences that don't convey clear meanings. Usually, the adopted traditional teaching methods cause a conspicuous chasm between the students' ability to write in English and achievement. Students with LDs have special kinds of problems different from regular students. Teachers need to understand their characteristics to use teaching methods and techniques appropriate to such category and to achieve the highest performance from them.

The researcher believed that it's significant to investigate the new methods that happened recently because of the shift to E-learning due to the spread of the COVID-19 pandemic all over the world. Furthermore, the researcher thought that it's significant to give the study participants a space to express their attitudes toward using virtual classes in teaching writing skills in English to students with learning disabilities. Therefore, this study attempted to investigate teachers' attitudes toward using virtual classrooms in teaching writing skills to students with LDs in Irbid city, Jordan.

\section{Significance of the study}

The concepts of technological pedagogies have become common trends in the field of teaching languages, including English. Understanding the nature and effect of these technologies is very important. Therefore, this study was established to understand the attitudes toward such modern technologies as used by English teachers to teach students with LDs. This study will help teachers and education specialists to understand the use of virtual classes and their effectiveness. At the school level, using virtual classes in the Jordanian educational context is still immature, so this study helps administrators, teachers, and students to get initial perceptions about e-learning and virtual classes.

\section{Limitations}

This study was limited to teachers of learning disabilities in English language in Irbid city, Jordan, during the school year 2019/2020. The study is also limited to the application of the instrument developed to collect data from the sample, and to the accuracy of the responses of the teachers.

\section{Literature Review}

The advent of technology as a significantly didactic tool has always been the surge that a wide range of research investigates. The intertwined processes of teaching and learning languages are completely dynamic, context-bound, and evolutionary, so there has been an accelerative flow of knowledge and technological inducements in the present era (Khasawneh, 2020). As Martin \& Parker (2014) show, the utilization of technology, to its full extent, is labeled as the utmost modern phenomena that most researchers, teachers, students, and even administrators adopt to improve the efficacy of learning languages through new methods (Khasawneh, 2019).

Many recent research trends deliver obscure and paradoxical perceptions about the practical uses of the technological modules that are usually tailored to improve the students' level of writing, language proficiency, and communication (Wichadee, 2013). It is not easy to provide clear-cut answers about such teaching areas because writing is a developmental skill that takes long periods to manifest itself; also, distance learning is still immature and hazy. Researchers need to tailor general principled approaches in a manner that suits many contextual, academic, social, and technological diversities that exist in education generally (Arkorful \& Abaidoo, 2014).

E-learning, virtual classes, task-based activities, teaching English writing, and anxiety are very

Copyright $\odot$ 2021, Journal of Asian Multicultural Research for Social Sciences Study, Under the license CC BY-SA 4.0 
important elements in the current situation after the COVID-19 pandemic (Khasawneh, 2021). There has always been an exigent need to tailor a comprehensive approach that harmoniously combines the aforementioned elements to address the aspirations of the new generations (Khasawneh, 2021). On the other hand, Bader (2015) stresses the fact that the use of technology in teaching must not be haphazard and overwhelming. Therefore, it is significant to explore the theoretical and empirical frameworks that set the basis of any fruitful technologized teaching approaches (Khasawneh, 2021).

The term e-learning has always been expansive, field-bound, and hard to define (Khasawneh, 2021). In other words, e-learning has been developed differently in the field of education, commerce, and social sciences (Khasawneh, 2021). It has widely different forms, implications, and uses, so it is complex to tailor fixed theoretical and empirical frameworks that show how language teaching and technology harmonize generally (Horton, 2001; Moore et al., 2011; Nicholson, 2007). Pedagogically speaking, there is a vast consent among many researchers that e-learning simply occurs when students are engaged in computer-based instructional practices inside and outside their classrooms; such learning may occur in the school computer labs, at home, or anywhere (Nagarajan \& Jiji, 2010). The aforementioned definition is oversimplified and concise; however, it introduces the five major constituents of e-learning that are; students, teachers, computers, a learning purpose and a sustained learning environment (Khasawneh, 2021).

Virtual classrooms have been established as a correspondence to the requirements of the global openness in which technology has played a significant role (Khasawneh, 2021). Virtual classrooms have gained popularity recently for their immense advantages; they help students who live in remote areas to have equal learning opportunities similar to their colleagues in cities (Martin \& Parker, 2014).

Activity theory, socio-cultural and socio-historical theories set the rational base of using virtual classes, as a computer-based tool and a continuum, in teaching (Gedera, 2014). Human activities, including learning, are mediated by cultural artifacts, which are culturally, historically, and socially produced and reproduced, using complex and multidimensional relationships. Therefore, learning languages should be perceived as a human activity that entails several levels of interactions and relationships such as, social and cultural exchanges (Martin \& Parker, 2014).

Alodwan and Ibnian (2014) point out that teaching writing as a product is sequenced, linear and passive. In this approach, teachers only focus on the final product, check any mistakes, and give grades. On the other hand, the process-oriented approach emphasizes interaction and authenticity. Teachers and students work collaboratively to develop skills and create meaning gradually ((Khasawneh, 2021). This is the purpose of using virtual classes to teach students with learning disabilities. It is very important to make classes interactive and supportive of the needs of such a category of students.

\section{Previous Studies}

Petretto et al (2021) conducted a systematic review of the literature conducted on the positive and negative effects of the use of Distance Learning and E-learning in students with LDs. The review gathered information from different databases, such as Scopus, Eric, and Google Scholar. The findings revealed that E-learning and distance learning was effective in the period of the COVID-19 pandemic and provided students with the necessary tools to complete their learning ((Khasawneh, 2021). The results also showed the importance of improving e-learning tools to enhance students' engagement in the educational process and provide teachers with all the tools they need. 
Svalina and Ivic (2020) investigated the impact of using virtual classes on the development and mastery of English language. The study was focused on one student with learning disabilities, who was included in a virtual class of regular students. The technology used in this class was the mobile application Edmodo (Khasawneh, 2021). The study used interviews to understand the development of the student. The findings revealed several challenges in using virtual classrooms, such as the teacher's experience, the lack of support from the teacher, the unreadiness of students, and the complexity of the materials (Khasawneh, 2021).

Rice (2018) explored the strategies to design specific courses to teach students with learning disabilities using virtual classes. These courses were intended to be accessible to this category of students. The results of the investigation revealed the availability of three strategies ((Khasawneh, 2021). These strategies were composing clear articulations of learning objectives, promoting personalized and contextualized learning and planning for visual and audio representation of concepts (Khasawneh, 2021). The findings also revealed that course designers showed an understanding of accessibility, but they should pay more attention to the abilities of students to engage in such courses (Khasawneh, 2021).

Terrazas-Arellanes et al (2018) explored the use of an online course in developing science learning among students with learning disabilities. The study was a project that was implemented over three years, where 2,303 students and 71 teachers were involved in the course. The study collected data before and after the implementation of the course. The results revealed improvement in the levels of students due to the use of online learning to teach students with learning disabilities (Khasawneh, 2021).

Helm (2015) presented a large-scale survey to scrutinize the practices and the barriers that collaboration underpins across the European universities. The results of the survey showed that communication was a highly fruitful tool for collaboration, but utilizing it underpinned numerous problems like time shortage, technical difficulties, and content uncertainties (Khasawneh, 2021). In a conclusion, the researcher pointed out that larger studies are significantly needed to reach a better understanding of communication and education (Khasawneh, 2021).

\section{Methods}

The study used the descriptive approach in collecting and analyzing data from the sample.

\section{Sampling}

The sample of the study consisted of 65 teachers of LDs in the English language from Irbid city, Jordan. They were randomly chosen from a total number of teachers of English language. The majority of the participants came from similar social, economic, and academic environments. Furthermore, pseudonyms were used in this research to warrant the participants' privacy and avoid the embarrassment that might take place due to any social, academic, and technical complications.

\section{Instrument of the study}

The study developed a questionnaire as an instrument. The questionnaire was divided into two complementary parts that emphasized several attitudes towards the interactive and the academic realms of e-learning. To illustrate, the first part was tailored to target the participants' demographic data, ability to access the net from home, and anxiety. Such data were presented because they gave the researcher initial perceptions about the accumulated attitudes that the participants held towards e-learning.

The second part of the questionnaire was designed to investigate the teachers' attitudes towards e-learning and virtual classrooms in detail. It's divided into two domains summarized as 
follows: 1. The first one consisted of seventeen items that tackled general beliefs and attitudes towards e-learning. The second one, which consisted of 18 items, targeted the effects of elearning on writing skills in particular.

\section{Validity}

The validity of the questionnaire was ensured by presenting it to a group of judges from university faculty members. The judges provided their opinions on the wording and accuracy of the statements of the questionnaire. After deleting and modifying some statements, the questionnaire was in its final form 34 items. Consequently, the last version of the questionnaire included two aspects about the general attitudes and the effects of e-learning on writing skill.

\section{Reliability}

The stability of the instrument of the study was verified by applying the questionnaire on a pilot sample from outside the actual sample of the study. The same questionnaire was applied after two weeks on the same sample. Eventually, the reliability of the questionnaire was systematically calculated by using Cronbach Alpha Coefficient, and it was measured in the following table:

Table 1. The internal consistency of the questionnaire (Cronbach's Alpha Coefficient)

\begin{tabular}{|l|l|}
\hline \multicolumn{1}{|c|}{ Domain } & Alpha \\
\hline Beliefs and attitudes towards e-learning & 0.76 \\
\hline The effectiveness of e-learning on developing the EFL students' writing skills & 0.78 \\
\hline Total Degree & 0.87 \\
\hline
\end{tabular}

As listed in the above table, the total alpha value of the adopted questionnaire was (0.87). This showed a high degree of trustworthiness and consistency about the two domains included in the questionnaire (the general beliefs and attitudes towards e-learning) and (the effectiveness of e-learning on the participants' writing skills).

\section{Results and discussion}

\section{Results of the first question}

The following tables systematically show the means and the standard deviations for the responses of teachers on the items of the questionnaire according to its two domains.

First: Attitudes towards the general realms of e-learning

Table 2. The means and the std. deviations of the teachers' general attitudes towards elearning (arranged by their importance)

\begin{tabular}{|c|l|l|c|c|}
\hline Item \# & \multicolumn{1}{|c|}{ Item } & Mean & Std. Deviation & Degree \\
\hline 9 & $\begin{array}{l}\text { E-learning improves the students' } \\
\text { attitudes towards writing. }\end{array}$ & 4.03 & 0.92 & High \\
\hline 3 & $\begin{array}{l}\text { E-learning is an interesting platform to } \\
\text { enhance English writing skills. }\end{array}$ & 4.03 & 0.81 & High \\
\hline 11 & $\begin{array}{l}\text { E-learning gives students the } \\
\text { opportunity to surf the net and read } \\
\text { about the topic required. }\end{array}$ & 3.97 & 0.98 & High \\
\hline 8 & $\begin{array}{l}\text { E-learning enables students to have } \\
\text { access to resources anytime. }\end{array}$ & 3.94 & 1.22 & High \\
\hline 10 & $\begin{array}{l}\text { E-learning enhances the students' } \\
\text { knowledge about writing. }\end{array}$ & 3.88 & 0.86 & High \\
\hline
\end{tabular}




\begin{tabular}{|c|c|c|c|c|}
\hline 12 & $\begin{array}{l}\text { E-learning provides authentic tasks } \\
\text { that } \\
\text { develop the students' critical thinking. }\end{array}$ & 3.79 & 1.08 & High \\
\hline 14 & $\begin{array}{l}\text { E-learning makes the writing process } \\
\text { more interactive. }\end{array}$ & 3.73 & 0.91 & High \\
\hline 15 & $\begin{array}{l}\text { E-learning gives students the chance to } \\
\text { receive immediate feedback from } \\
\text { teacher. }\end{array}$ & 3.70 & 1.13 & High \\
\hline 4 & $\begin{array}{l}\text { E-learning increases interaction with } \\
\text { teachers. }\end{array}$ & 3.70 & 1.13 & High \\
\hline 16 & $\begin{array}{l}\text { E-learning encourages students to use } \\
\text { writing as a means of communication } \\
\text { with teachers and classmates. }\end{array}$ & 3.67 & 1.02 & Average \\
\hline 5 & $\begin{array}{l}\text { E-learning makes teaching students- } \\
\text { centered rather than teacher-centered. }\end{array}$ & 3.67 & 0.89 & Average \\
\hline 17 & $\begin{array}{l}\text { E-learning triggers students to read in } \\
\text { order to attain ideas about the topic } \\
\text { they want to write about }\end{array}$ & 3.64 & 1.14 & Average \\
\hline 6 & $\begin{array}{l}\text { E-learning enhances students' } \\
\text { responsibility for their learning. }\end{array}$ & 3.64 & 1.03 & Average \\
\hline 7 & $\begin{array}{l}\text { E-learning enhances the students' } \\
\text { motivation. }\end{array}$ & 3.48 & 0.91 & Average \\
\hline 13 & $\begin{array}{l}\text { E-learning provides authentic tasks } \\
\text { that } \\
\text { develop the students' creativity. }\end{array}$ & 3.45 & 1.09 & Average \\
\hline 1 & $\begin{array}{l}\text { E-learning encourages students to } \\
\text { work } \\
\text { collaboratively with their classmates. }\end{array}$ & 3.39 & 0.90 & Average \\
\hline 2 & $\begin{array}{l}\text { E-learning engages students in the } \\
\text { learning process more than the } \\
\text { traditional learning. }\end{array}$ & 3.36 & 0.82 & Average \\
\hline & The total degree of the domain & 3.71 & 0.59 & High \\
\hline
\end{tabular}

The results showed that the teachers' general attitudes towards e-learning were high with an total mean of (3.71). Extraordinarily, the most significant items, scored by the teachers, targeted the paradoxical realms that the study underpinned (attitudes and skill development). Both items number 3 and 9 got the same mean score (4.03). however, these results show that teachers have good attitudes toward using e-learning and virtual classrooms in teaching students with learning disabilities.

Second: The attitudes towards the linguistic realms of e-learning

Table 3. The means and the std. deviations of the teachers' attitudes towards the effects of elearning on the English writing skills (arranged by their importance)

\begin{tabular}{|c|l|c|l|c|}
\hline Item \# & \multicolumn{1}{|c|}{ Item } & Mean & Std. Deviation & Degree \\
\hline 5 & $\begin{array}{l}\text { E-learning helps students to develop } \\
\text { punctuation awareness. }\end{array}$ & 4.12 & 0.86 & High \\
\hline 12 & $\begin{array}{l}\text { E-learning helps students to } \\
\text { brainstorm ideas } \\
\text { before writing. }\end{array}$ & 3.97 & 1.19 & High \\
\hline
\end{tabular}




\begin{tabular}{|c|c|c|c|c|}
\hline 14 & $\begin{array}{l}\text { E-learning helps students to develop } \\
\text { the ability to revise writing. }\end{array}$ & 3.94 & 0.83 & High \\
\hline 3 & $\begin{array}{l}\text { E-learning helps students to achieve } \\
\text { better } \\
\text { language flow in writing. }\end{array}$ & 3.91 & 0.77 & High \\
\hline 1 & $\begin{array}{l}\text { E-learning helps students to develop } \\
\text { vocabulary reservoir. }\end{array}$ & 3.88 & 1.02 & High \\
\hline 13 & $\begin{array}{l}\text { E-learning helps students to plan } \\
\text { writing. }\end{array}$ & 3.79 & 0.99 & High \\
\hline 16 & $\begin{array}{l}\text { E-learning helps students to have a } \\
\text { better } \\
\text { writing organization. }\end{array}$ & 3.79 & 0.74 & High \\
\hline 7 & $\begin{array}{l}\text { E-learning helps students to develop } \\
\text { stylistically } \\
\text { awareness. }\end{array}$ & 3.73 & 0.94 & High \\
\hline 6 & $\begin{array}{l}\text { E-learning helps students to develop } \\
\text { spelling } \\
\text { skills. }\end{array}$ & 3.73 & 1.01 & High \\
\hline 2 & $\begin{array}{l}\text { E-learning helps students to achieve } \\
\text { better } \\
\text { cohesion and coherence in writing }\end{array}$ & 3.67 & 0.78 & Average \\
\hline 4 & $\begin{array}{l}\text { E-learning helps students to develop } \\
\text { syntactic awareness. }\end{array}$ & 3.58 & 0.83 & Average \\
\hline 17 & $\begin{array}{l}\text { E-learning helps students to develop } \\
\text { the ability to write introductions and } \\
\text { conclusions. }\end{array}$ & 3.52 & 0.97 & Average \\
\hline 15 & $\begin{array}{l}\text { E-learning helps students to develop } \\
\text { the ability to edit writing. }\end{array}$ & 3.48 & 1.15 & Average \\
\hline 8 & $\begin{array}{l}\text { E-learning helps students to develop } \\
\text { capitalization awareness. }\end{array}$ & 3.39 & 1.06 & Average \\
\hline 11 & $\begin{array}{l}\text { E-learning helps students to develop } \\
\text { morphological awareness. }\end{array}$ & 3.36 & 0.74 & Average \\
\hline 10 & $\begin{array}{l}\text { E-learning helps students to develop } \\
\text { discourse awareness. }\end{array}$ & 3.36 & 0.99 & Average \\
\hline 9 & $\begin{array}{l}\text { E-learning helps students to develop } \\
\text { verbs use }\end{array}$ & 3.33 & 0.99 & Average \\
\hline & The total degree of the domain & 3.65 & 0.51 & Average \\
\hline
\end{tabular}

The results showed that the mean scores of the teachers' attitudes towards the efficacy of elearning on the writing skills were average; the mean value was equal to (3.65). The item that got the highest score was item 5 "E-learning helps students to develop punctuation awareness." These results show that the teachers' attitudes toward the role of e-learning and virtual classes were of moderate estimations. Most teachers believed that virtual classes are helpful while some of them see some challenges. According to teachers' views, several problems arise when implementing virtual classes, especially with students with LDs.

\section{Results of the second question}

To identify the differences in the views of male and female teachers, the study used the independent t-test for the two domains of the questionnaire as shown in the following tables. 
Table 4. The results of the independent t-test about the teachers' general attitudes towards elearning according to gender

\begin{tabular}{|l|r|l|l|l|c|c|}
\hline Gender & N & Mean & Std. Deviation & T & d.f. & Sig. \\
\hline Males & 32 & 3.32 & 0.48 & 2.894 & 63 & 0.005 \\
\hline Females & 33 & 3.71 & 0.59 & & & \\
\hline
\end{tabular}

The results of the t-test indicated that there were significant differences regarding the teachers' general attitudes towards e-learning between male and female teachers $(p=0.005<0.05)$. The differences were in favor of female teachers because they manifested more positive attitudes towards e-learning by a mean value that's equal to (3.71) compared to (3.32) for male teachers. Female teachers have more keenness to use e-learning and virtual classes more than male teachers. This is might be due to the nature of culture and societal practices. Female teachers show more enthusiasm toward using new techniques and methods in teaching.

As for the second domain of the questionnaire, the independent t-test was utilized to target the teachers' attitudes towards the linguistic realms of e-learning. The results are shown in the following table.

Table 5. The results of the independent t-test about the teachers' attitudes towards the linguistic realms of using e-learning

\begin{tabular}{|l|c|l|c|c|c|c|}
\hline Gender & N & Mean & Std. Deviation & T & d.f. & Sig. \\
\hline Males & 32 & 3.29 & 0.51 & 2.886 & 63 & 0.005 \\
\cline { 1 - 4 } Females & 33 & 3.65 & 0.51 & & & \\
\hline
\end{tabular}

The results of the t-test indicated that there were significant attitudinal differences between female and male teachers $(\mathrm{p}=0.005<0.05)$. Such differences were in favor of female teachers as they expressed more positive attitudes towards learning English writing online by a mean value that's equal to (3.65) compared to (3.29) for male teachers.

\section{Conclusion}

Interestingly, the values of the standard deviations were relatively high and similar to each other. This showed that the teachers manifested greatly variant predispositions towards the effectiveness of using virtual classes to learn English writing. This disparity of attitudes, within the same group, and between both groups, was ordinary due to three major reasons. First, the targeted participants came from different schools. Some of these schools were equipped with opportune technological facilitation; however, others in remote areas didn't even have computers. Second, attitudes and computer availability at home were closely related to each other. Some teachers believe that their students were able to go online at any time; however, others didn't own a computer at home.

\section{Recommendations}

The study recommends conducting more training for teachers on the use of virtual classes and the techniques of e-learning. The education administration must ensure the availability of equipment and tools for both teachers and students to be able to complete the learning process. The study also recommended conducting more studies on other samples from other areas on the use of virtual classes and e-learning to teach students with LDs writing skills in English.

\section{Acknowledgments}


The authors extend their appreciation to the Deanship of Scientific Research at King Khalid University for funding this work through Big Research Groups under grant number (RGP.2 /103/42).

\section{References}

Alkhawaldeh, M. A. (2020). and Mohamad Ahmad Saleem Khasawneh (2020). The Impact of Using an Infographic-based Training Program on Improving Visual Motor Memory Among EFL Student. INDIAN JOURNAL OF SCIENCE AND TECHNOLOGY, 405416. DOI: $10.17485 / \mathrm{ijst} / 2020 / \mathrm{v} 13 \mathrm{i} 04 / 148906$

Alkhawaldeh, M. A., \& Kha-sawneh, M. A. S. (2020). Developing acoustic analysis skills among students with developmental apraxia of speech (DAS). Indian Journal of Science and Technology, 13(22), 2237-2244. DOI: 10.17485/ijst/v13i22.148932

Alkhawaldeh, M. A., \& Khasawneh, M. A. S. (2021). Learning Disabilities in English at the Primary Stage: A Qualitative Study from the Students' Perspective. http://ijmrap.com/wp-content/uploads/2021/06/IJMRAP-V3N12P107Y21.pdf

Alkhawaldeh, M. A., \& Khasawneh, M. A. S. (2021). The availability of teaching aids in resource rooms and their use by teachers in Irbid Governorate. Science and Education, 2(8),390-401.

https://openscience.uz/index.php/sciedu/article/view/1772/1694

Alodwan, T. A., \& Ibnian. S. S. (2014). The Effect of Using the Process Approach to Writing on Developing University Students' Essay Writing Skills in EFL. Review of Arts and Humanities, 3(2) 139-155.

Arkorful, V., \& Abaidoo, N. (2014). The role of e-learning, the advantages and disadvantages of its adoption in Higher Education. International Journal of Education and Research, 2(12), 397-410.

Bader, H. E. (2015). Blended Learning in Tertiary ELT. Deutschland: Lap Lambert Academic Publishing.

Gedera, D. S. (2014). Students' experiences of learning in a virtual classroom. International Journal of Education and Development using Information and Communication Technology, 10(4), 93-101.

Harper, K. C., Chen, K., \& Yen, D. C. (2004). Distance learning, virtual classrooms, and teaching pedagogy in the Internet environment. Technology in Society, 26(4), 585598.

Horton, W. K. (2001). Leading E-learning. USA: the American Society for Training \& Development.

Khasawaneh, M., \& Arabia, S. (2016). The Impact of a Training Program Based on the Visual Words Composition Techniques on the Development of Reading Comprehension Skills among the Students of Primary Stage. Advances in Bioresearch, 7(2). https://www.researchgate.net/publication/329091984_International_Journal_of_Aca demic_Research

Khasawneh, M. (2021). The Relationship of Curriculum, Teaching Methods, Assessment Methods, and School and Home Environment with Learning Difficulties in English Language from the Studetns' Perspectives. Journal of Innovation in Educational and Cultural Research, 3(1), 41-48. https://doi.org/10.46843/jiecr.v3i1.51 
Khasawneh, M. A. (2012). Spatial ability for children with learning disabilities in hail and its relationship with some variables. European Scientific Journal, 8(22).

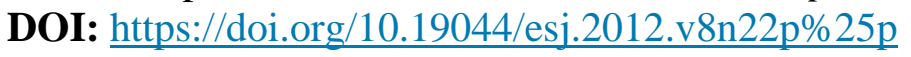

Khasawneh, M. A. (2019). Using Social Media Networks by Learning Disabilities Teachers. International Journal of Educational Research Review, 4, 766-780. https://doi.org/10.24331/ijere.634880

Khasawneh, M. A. (2021). The effect of the spread of the new COVID-19 on the psychological and social adaptation of families of persons with disabilities in the Kingdom of Saudi Arabia. Health Psychology Report, 9(3),

264-275. DOI: https://doi.org/10.5114/hpr.2020.99003

Khasawneh, M. A. (2021). The effect of the spread of the new COVID-19 on the psychological and social adaptation of families of persons with disabilities in the Kingdom of Saudi Arabia. Health Psychology Report, 9(3), 264-275. DOI: https://doi.org/10.5114/hpr.2020.99003

Khasawneh, M. A. S. (2020). The Extent of Bullying Against Students with Learning Disabilities According to the Age Variable. International Journal of Learning, Teaching and Educational Research, 19(6), 267-281. DOI: 10.26803/ijlter.19.6.16

Khasawneh, M. A. S. (2020). The leadership roles of Saudi special education teachers from their own perspectives. Indian Journal of Science and Technology, 13(25), 25202528. DOI: $10.17485 / \mathrm{ijst} / \mathrm{v} 13 \mathrm{i} 25.110$

Khasawneh, M. A. S. (2020). THE SPATIAL ABILITY OF SCHOOL STUDENTS WITH LEARNING DISABILITIES IN SAUDI ARABIA. https://www.researchgate.net/publication/340332933_THE_SPATIAL_ABILITY_O F_SCHOOL_STUDENTS_WITH_LEARNING_DISABILITIES_IN_SAUDI_ARA BIA

Khasawneh, M. A. S. (2021). An electronic training program to treat errors of reading aloud in the English language among students with learning difficulties during the emerging Covid-19. The Journal of Quality in Education,11(17), 49-69. https://doi.org/10.37870/joqie.v11i17.251

Khasawneh, M. A. S. (2021). Challenges resulting from simultaneous online education during the" Covid-19" pandemic: the case of King Khalid University, Saudi Arabia. Science and Education, 2(8), 414-430. https://openscience.uz/index.php/sciedu/article/view/1774/1696

Khasawneh, M. A. S. (2021). Cognitive Flexibility of Students with Learning Disabilities in English Language and Its Relationship to Some Variables. Shanlax International Journal of Education, 9(3), 49-56. DOI: 10.34293/education.v9i3.4003

Khasawneh, M. A. S. (2021). Language skills and their relationship to learning difficulties in English language from the students' point of view. Science and Education, 2(9), 261272. DOI: $10.34293 /$ education.v9i4.4082

Khasawneh, M. A. S. (2021). Methods of resource room management for teachers of learning disabilities in English language in light of some variables. Science and Education, 2(9), 240-249. DOI: 10.30659/e.6.2.213-221

Khasawneh, M. A. S. (2021). Obstacles to using e-learning in teaching English for students with learning disabilities during the Covid-19 pandemic from teachers' point of 
view. Science

and

Education, 2(5),

470-483.

https://openscience.uz/index.php/sciedu/article/view/1406/1350

Khasawneh, M. A. S. (2021). Problems Teaching English to Deaf Students. Indonesian Journal of Creative Counseling, 1(2), 32-42. DOI: https://doi.org/10.47679/ijcc.v1i2.107

Khasawneh, M. A. S. (2021). Social competence for students with learning disabilities in English. Technium Social Sciences Journal,23(1), 16-27. Retrieved from https://techniumscience.com/index.php/socialsciences/article/view/4439

Khasawneh, M. A. S. (2021). Teacher Perspective on Language Competences Relation to Learning Difficulties in English Learning. Journal Educational Verkenning, 2(1),2937. Retrieved from http://hdpublication.com/index.php/jev/article/view/125

Khasawneh, M. A. S. (2021). The degree of practicing effective communication skills among teachers of learning disabilities in English language from their point of view. Journal Educational Verkenning, 2(2), 1-9. DOI: 10.47616/jamres.v2i2.175

Khasawneh, M. A. S. (2021). The Effect of Using a Language Games-Based Electronic Program on Acquiring Oral Expression Skills among People with Learning Difficulties in English Language during Covid-19 Pandemic. MANAZHIM, 3(2), 136150. https://doi.org/10.36088/manazhim.v3i2.1109

Khasawneh, M. A. S. (2021). The Effect of Using a Language Games-Based Electronic Program on Acquiring Oral Skills. Experiences of Adult English Learners during the COVID-19 Pandemic. Edukacja Ustawiczna Dorostych, 112(1), 13-24. https://doi.org/10.36088/manazhim.v3i2.1109

Khasawneh, M. A. S. (2021). The effectiveness of a training program based on Erikson's theory in developing independence skills among students with learning disabilities in Jordan. Science and Education, 2(8), 457-471. https://openscience.uz/index.php/sciedu/article/view/1776/1698

Khasawneh, M. A. S. (2021). The effectiveness of using multimedia in the developing the concepts of the English language grammar concepts for people with learning difficulties. Science and Education, 2(6), 373-384. https://openscience.uz/index.php/sciedu/article/view/1571/1505

Khasawneh, M. A. S. (2021). The extra-curricular environmental activities as practiced by English language students with learning difficulties from their teachers' point of view. Science and Education, 2(4), 275-287. https://openscience.uz/index.php/sciedu/article/view/1226/1177

Khasawneh, M. A. S. (2021). The Level of Emotional Intelligence of English Language Students with Learning Disabilities from the Point of View of Their Parents. Science and Education, 2(7),

264-275. https://openscience.uz/index.php/sciedu/article/view/1706/1635

Khasawneh, M. A. S. (2021). The Level of Morale Among Teachers of Learning Disabilities in English Language in Irbid, Jordan. Journal La Edusci, 2(3), 29-36. https://doi.org/10.37899/journallaedusci.v2i3.432

Khasawneh, M. A. S. (2021). The level of stuttering severity among students with learning disabilities in English language. Science and Education, 2(9), 215-226. https://openscience.uz/index.php/sciedu/article/view/1842/1747 
Khasawneh, M. A. S. (2021). The reality of extra-curricular educational activities from the viewpoint of students with learning difficulties in English language. 6-2-13-161 (2).pdf

Khasawneh, M. A. S. (2021). The relationship between the acquisition of language patterns and oral expression skills among students with learning difficulties in the English language during the Covid-19 pandemic. Science and Education, 2(5), 490-499. https://openscience.uz/index.php/sciedu/article/view/1408/1352

Khasawneh, M. A. S. (2021). THE USE OF DEMOCRATIC STYLE BY TEACHERS OF LEARNING DISABILITIES IN ENGLISH LANGUAGE ACCORDING TO SOME VARIABLES. language, 4(05). https://ijehss.com/uploads2021/EHS_4_305.pd

Khasawneh, M. A. S. (2021). The use of Laissez-faire style by teachers of Learning Disabilities in English language according to some variables. Science and Education, 2(9), 250260. https://openscience.uz/index.php/sciedu/article/view/1845/1750

Khasawneh, M. A. S. (2021). The Use of Reading Speed Strategy in Promoting Reading Comprehension among EFL Students with Learning Disabilities. Al-Lisan: Jurnal Bahasa (e-Journal), 6(2), 225-235. https://doi.org/10.30603/al.v7i2.2135.

Khasawneh, M. A. S. (2021). The Use of Reading Speed Strategy in Promoting Reading Comprehension among EFL Students with Learning Disabilities. Al-Lisan: Jurnal Bahasa (e-Journal), 6(2), 225-235 https://doi.org/10.30603/al.v7i2.2135

Khasawneh, M. A. S. (2021). Training program on developing reading skills in the english language among students with learning difficulties. Revista EDUCARE-UPEL-IPBSegunda Nueva Etapa 2.0, 25(1), 84-101. DOI: 10.46498/reduipb.v25i1.1466

Khasawneh, M. A. S. K. (2021). Work pressures among teachers of learning disabilities in English language from their point of view. Journal of Asian Multicultural Research for Educational Study, 2(2), 15-23. DOI: 10.47616/jamres.v2i2.177

Khasawneh, M. A. S. K. (2021).Self-Regulation among students with learning disabilities in English language and its relationship to some variables. https://socialscienceresearch.org/index.php/GJHSS/article/view/3660/3549

Khasawneh, M. A. S. K. (2021).The effectiveness of a training program based on Erikson's theory in developing initiation skills among students with learning disabilities in Jordan.

Khasawneh, M. A. S., \& Alkhawaldeh, M. A. (2018). The Relationship between Successful Intelligence and School-Social Growth among Learning Disability Students in Aseer Area. Basic Education College Magazine For Educational and Humanities Sciences, (39).

Khasawneh, M. A. S., \& Alkhawaldeh, M. A. (2020). The Effectiveness of Phonological Awareness Training in Treating Deficiencies in Auditory Processing Among Children with Learning Disabilities Among Elementary Cycle Students in Saudi Arabia. International Journal of Language Education, 4(3). https://doi.org/10.26858/ijole.v4i3.14758

Khasawneh, M. A. S., \& Alkhawaldeh, M. A. H. (2017). The attitudes of King Khalid's students who are affiliated with Special Education bachelor's degree toward Blackboard Software in their learning. International Journal of Humanities and Cultural Studies (IJHCS) ISSN 2356-5926,2(4), 2789-2798. https://www.ijhcs.com/index.php/ijhcs/article/view/3061/2888 
Khasawneh, M. A. S., \& Al-Rub, M. O. A. (2020). Development of Reading Comprehension Skills among the Students of Learning Disabilities. Universal Journal of Educational Research, 8(11), 5335-5341. DOI: 10.13189/ujer.2020.081135

Khasawneh, M. A. S., Alkhawaldeh, M. A., \& Hamad, H. A. A. B. (2018). Building a training program based on the theory of voice awareness and measuring its effectiveness in developing the skills of auditory analysis of students with difficulties in synergy, developmental and verbal Verbal Dyspraxia. Basic Education College Magazine For Educational and Humanities Sciences, (41).

Khasawneh, M. A., Al Ahmad, F. A., \& Al Khawaldeh, M. A. (2018). the Effects of Training Program based on Auditory Perception Skills in Enhancing Phonological Awareness among Learning Disability Students in Aseer Region. Journal of Educational and Psychological Studies [JEPS], 12(3), 591-604. https://doi.org/10.24200/jeps.vol12iss3pp591-604

Khasawneh, M., Alkhawaldeh, M., \& Al-Khasawneh, F. (2020). The Level of Metacognitive Thinking Among Students with Learning Disabilities. International Journal of English Linguistics, 10(5). doi:10.5539/ijel.v10n5p343

Khasawneh, MAS (2021). Training program for the development of reading skills in English for students with learning difficulties. EDUCARE-UPEL-IPB-Second New Stage 2.0 Magazine , 25 (1), 84-101. DOI: 10.46498/reduipb.v25i1.1445

Martin, F., \& Parker, M. A. (2014). Use of Synchronous Virtual Classrooms: Why, Who, and How? MERLOT Journal of Online Learning and Teaching, 10(2), 192-210.

Moore, J. L., Dickson-Deane, C., \& Galyen, K. (2011). E-Learning, online learning, and distance learning environments: Are they the same? Internet and Higher Education, 14(2), 129-135.

Nagarajan, P., \& Jiji, G. W. (2010). Online Educational System (e-learning). International Journal of $u$ - and e-Service, Science and Technology, 3(4), 37-48.

Nicholson, P. (2007). A History of E-Learning. In B. Fernández-Manjón, J. M. Sánchez- Pérez, J. A. Gómez-Pulido, M. A. Vega-Rodríguez, \& J. Bravo-Rodríguez (Eds.), Computers and Education: E-Learning, From Theory to Practice (pp. 1-11).Sayed, M., \& Baker, F. (2015). E-Learning Optimization Using Supervised Artificial Neural- Network. Journal of Software Engineering and Applications, 8, 26-34. Retrieved from https://file.scirp.org/pdf/JSEA_2015012114443529.pdf

Petretto, D. R., Carta, S. M., Cataudella, S., Masala, I., Mascia, M. L., Penna, M. P., ... \& Masala, C. (2021). The Use of Distance Learning and E-learning in Students with Learning Disabilities: A Review on the Effects and some Hint of Analysis on the Use during COVID-19 Outbreak. Clinical Practice and Epidemiology in Mental Health, 17(1).

Rice, M. F. (2018). Supporting Literacy with Accessibility: Virtual School Course Designers' Planning for Students with Disabilities. Online Learning, 22(4), 161-179.

Svalina, V., \& Ivic, V. (2020). Case Study of a Student with Disabilities in a Vocational School during the Period of Online Virtual Classes Due to COVID-19. World Journal of Education, 10(4), 115-123.

Terrazas-Arellanes, F. E., Gallard M, A. J., Strycker, L. A., \& Walden, E. D. (2018). Impact of interactive online units on learning science among students with learning disabilities and English learners. International Journal of Science Education, 40(5), 
498-518.

Wichadee, S. (2013). Improving Students' Summary Writing Ability through Collaboration: a comparison between Online Wiki Group and Conventional Face-to-Face Group. The Turkish Online Journal of Educational Technology, 12(3), 107-116 